\title{
Tax Transparency for an Effective Tax System
}

\author{
Kelbesa Megersa \\ Institute of Development Studies \\ 08 January 2021
}

\section{Question}

What evidence is there that transparency in the tax system is good and what are the benefits for example, rising revenue, strengthen citizen/state relationship, rule of law, etc.?

\section{Contents}

1. Overview

2. Tax Transparency Initiatives and Their Key Results

3. Tax Transparency and Citizen-State Relationship

4. Tax Transparency and Rule of Law

5. Potential Costs of Tax Transparency

6. Factors Limiting Wider Adoption of Tax Transparency Initiatives

7. References

The K4D helpdesk service provides brief summaries of current research, evidence, and lessons learned. Helpdesk reports are not rigorous or systematic reviews; they are intended to provide an introduction to the most important evidence related to a research question. They draw on a rapid deskbased review of published literature and consultation with subject specialists.

Helpdesk reports are commissioned by the UK Foreign, Commonwealth, and Development Office and other Government departments, but the views and opinions expressed do not necessarily reflect those of FCDO, the UK Government, K4D or any other contributing organisation. For further information, please contact helpdesk@k4d.info. 


\section{Overview}

Improvements in tax transparency can help in strengthening public finances in developing countries that are adversely affected by COVID-19. The current context (i.e. a global pandemic, widespread economic slowdown/recessions, and declining tax revenues) engenders the urgency of improving domestic resource mobilisation (DRM) and the fight against illicit financial flows (IFFs).

Even before the advent of COVID-19, developing countries' tax systems were facing several challenges, including weak tax administrations, low taxpayer morale and "hard-totax" sectors (IMF, OECD, UN and World Bank, 2011). This affects their DRM capabilities which are currently below their tax potential (Monkam et al., 2018; AU and ECA 2015).

The presence of informational asymmetry (i.e. low tax transparency) between taxpayers and tax authorities generates loopholes for abuse of the tax system. It allows the hiding of wealth abroad with a limited risk of being caught. Cases of such behaviour that are exposed without proper penalty may result in a decline in the morale of citizens and a lower level of voluntary compliance with tax legislation. A number of high-profile tax leaks and scandals have undermined public confidence in the fairness of tax systems and generated a strong demand for effective counteraction and tax transparency (OECD, 2019b; Global Forum, 2020).

One of the key contributing factors to lower tax revenues in developing countries (that is linked to low tax transparency) is a high level of IFFs. These flows, including international tax evasion and the laundering of corruption proceeds, build a major obstacle to successful DRM efforts. For example, the amount lost annually by African countries through IFFs is estimated to exceed USD 100 billion (ECA 2018). Poor tax transparency (revealed in the form of aggressive tax evasion) is, therefore, a major source of potential revenue leakage (Monkam et al., 2018; AU and ECA 2015; see also Section 3). ${ }^{1}$ Some developing countries have realised significant growth in their tax revenue and in the size of their taxpayers through transparency initiatives (including schemes encouraging citizens into voluntary income declarations). For instance:

- India succeeded in generating USD 6 billion in tax revenue from a new set of 65,000 taxpayers in 2016. This was realised through a voluntary income disclosure programme.

- Indonesia has been able to recently add a million taxpayers into its tax system and recover over USD 10 billion. This was achieved through a tax amnesty scheme provided in advance of the country's participation in the global transparency initiative under the OECD's Common Reporting Standard.

\footnotetext{
${ }^{1}$ Given the high levels of illicit financial flows from African countries and recognising the potential of tax transparency and exchange of information to raise resources for development, African members of the Global Forum on Transparency and Exchange of Information for Tax Purposes attending its plenary meeting on 28 October 2014 in Berlin decided to create an African focused programme: the Africa Initiative. The objective was to unlock the potential of tax transparency and exchange of information for Africa by ensuring that African countries are equipped to exploit the improvements in global transparency to better tackle tax evasion (Global Forum, 2020).
} 
- Nigeria has been able to grow the number of taxpayers in its database by about 5 million between 2016 and 2018. This was realised partly through a voluntary assets and income declaration scheme.

- Several developing countries (e.g. Cape Verde, Costa Rica, Georgia, Madagascar, Peru, Ukraine, and Viet Nam) are benefiting from technical assistance and capacity building programmes provided by the World Bank and Global Forum. These assistances are provided to meet global standards for tax transparency and exchange of information.

\section{Research has also identified an association between organisational transparency (e.g. transparency by businesses and tax authorities) and stakeholder trust (e.g. between} citizens and the state). However, the evidence is mixed as to how transparency in particular influences trust and perceptions of trustworthiness (Schnackenberg and Tomlinson, 2016). ${ }^{2}$ Some examples of country initiatives that enhanced tax transparency, and thereby, led to marked gains in tax revenue as well as better citizen-state relationship and trust include the following (see also section 4):

- In Ghana, the introduction of the 'associational taxation' system for taxing the informal sector has succeeded in bringing a large part of the informal sector into the Ghanaian tax system and in improving transparency. Traders in the informal sector (now paying taxes) have also experienced less police abuse and improved credibility. As a result, the process of working directly with community groups to raise tax revenue has enabled Ghana to restore the confidence of its citizens in the tax system and increased tax transparency. Such tax systems (and the related gains in tax transparency from the formalisation of business activities and revenues generated) would be especially useful in low-income economies where the informal sector is of significant size.

- In Guinea, a USAID project has helped the local government i) to link 'market taxes' (which are significant for the country) with the building of better market facilities for market traders and ii) also clearly communicate appropriate information on the market tax revenues and expenditures realised by these taxes.

- In Kenya, the use of 'Constituency Development Funds' (where a fixed share of central government tax revenue is allocated to individual Kenyan districts and granting the primary control over the allocations to local members of parliament) has enhanced tax transparency and strengthened tax-expenditure linkages to meaningfully affect the levels of citizen engagement - including in tax payments.

- In Uganda (and Ghana), the process of introducing VAT in the 1990s was characterised by low transparency and there was misunderstanding and fear by taxpayers that these new taxes would entail considerable price rises, at times leading to protests by citizens. The problem was a result of the low level of trust by citizens on the one hand and low transparency and public communication on the side of tax authorities and the governments. If the challenges around tax transparency are not improved, such problems

\footnotetext{
2 Schnackenberg and Tomlinson (2016) stress that transparency has three dimensions: information disclosure, clarity, and accuracy. In relation to transparency, they identify three issues of concern: i) the meaning of information quality, ii) the effects of transparency on organization-stakeholder relationships and iii) mechanisms that influence transparency perceptions.
} 
may continue to be witnessed in developing countries at times of major tax reforms (i.e. on existing tax systems) or the introduction of new taxes such as digital service taxes.

\section{Tax Transparency Initiatives and Their Key Results}

The implementation of the internationally agreed standards for tax transparency is helping to bridge the information asymmetry between taxpayers (i.e. citizens and businesses) and tax authorities. ${ }^{3}$ The key international standards (on enhanced transparency and exchange of information for tax purposes) include the following:

i) The Automatic Exchange of Financial Account Information (AEOI);

ii) The Exchange of Information on Request (EOIR) and;

iii) Tax Transparency and Exchange of Information (EOI).

Apart from recovering lost and unpaid taxes (e.g. on undeclared/hidden income and business activities), the availability of information to tax authorities has a deterrent effect by increasing the costs of potential future tax evasion. This enhances the belief of citizens in the fairness of the tax system and strengthens their motivations for tax compliance (Monkam et al., 2018).

Although international tax transparency initiatives are mainly designed for the control of the direct and asset taxes of multinational businesses and large fortunes, there is a positive spillover effect on national tax systems. This is especially the case for developing countries where better transparency in the tax system may help to strengthen VAT and other indirect taxes, which are more important than personal income taxes (Barreix et al., 2016). ${ }^{4}$

International tax transparency standards require every tax jurisdiction to reveal the ownership structure of legal entities and to ensure that tax administrations can obtain the information required to investigate the assets and activities of their taxpayers - no matter where they are carried out. The application of international transparency standards (e.g. EOI) for tax purposes addresses a variety of policy recommendations for combating IFFs, not only in the field of tax evasion, but also for other enablers of IFFs such as corruption and money laundering (Global Forum, 2020). ${ }^{5}$

International standards on tax transparency and the automatic exchange of tax information could generate a wide scope of benefits particularly to developing countries,

\footnotetext{
3 Intergovernmental co-operation aiming at addressing cross-border tax evasion - a major source of IFFs - has grown rapidly over the last 10 years. Two of its key standardised components are the Exchange of Information on Request Standard (EOIR) and the Automatic Exchange of Financial Account Information Standard (AEOI) (Global Forum, 2020).

${ }^{4}$ See composition of tax revenues in developing countries at https://ourworldindata.org/taxation

5 The average tax-to-GDP ratio of African countries was 17.2\% in 2017 (OECD, ATAF and AUC, 2019). Further, nearly half of the countries in Africa fall below the minimum level of $15 \%$ considered necessary to finance the basic services, such as road infrastructure, healthcare, and public safety (Global Forum, 2020; OECD, 2018).
} 
if correctly used. In particular, these schemes could give them access to the following benefits (Monkam et al., 2018):

- Better tax and financial information: i.e., availability of accurate and up-to-date information on ownership (legal and beneficial), accounting records, banking information. This may encourage improvements in reporting standards not only for big multinational businesses but also for smaller resident taxpayers.

- The digitalisation of tax administration: The assessment of confidentiality and data privacy benefits tax administration as a whole. The handling of AEOI data also improves tax systems, skills and knowledge and may enhance the quality and handling of locally accessible tax data.

- Better exchange of information: i.e., the establishment of a broad international EOI system, the enhancement of the responsiveness and quality of requests, and the establishment of access and handling processes for sensitive tax/financial information.

- Effectiveness of tax administration: i.e., access of tax authorities to the essential taxrelevant data by i) removing incompatible restrictions, e.g. bank and other professional secrecy, often also for domestic purposes and ii) tackling ineffective tax administration procedures.

- Better taxpayers' discipline: Third-party reporting has a track record of improving tax compliance by threatening credible litigation for tax fraud.

\subsection{OECD's Initiative for Common Reporting Standard and "Automatic Exchange of Financial Account Information":}

Over 90 countries (or tax jurisdictions) are currently participating in a global transparency programme under the OECD's Common Reporting Standard (CRS). Participating countries have shared details on over 47 million offshore accounts (with a cumulative amount of about EUR 4.9 trillion) between 2018 and 2019 (OECD, 2019a).

Particularly, the AEOI initiative, which has been enabled through 4,500 bilateral ties, marks the biggest exchange of tax information in history and the culmination of more than two decades of international efforts to fight tax evasion (OECD, 2019a).

AEOI allows financial institutions to automatically disclose information on the financial account of non-residents to their tax authorities who, in turn, share this information with the tax authorities of the account holder's country of residence under the internationally agreed CRS. This greatly increases the ability of tax authorities to detect tax evasion, even in cases where there was no initial evidence of non-compliance (Monkam et al., 2018).

Preliminary OECD estimates and assessments show the significant impact of the AEOI and its contribution to transparency in the field of taxes and financial account information. For example, deposits held by companies or individual citizens in more than 40 primary international financial centres (IFCs) grew dramatically over the 2000 to 2008 period, peaking at USD 1.6 trillion by mid-2008 (OECD, 2019a). Yet, over the last ten years (i.e. most of the 2000s), these deposits have dropped by $34 \%$, reflecting a decrease of USD 551 billion, since countries have enforced tougher transparency requirements. A significant part of this decrease is attributed to the onset of the AEOI initiative, which accounts for about two-thirds of 
the drop. Specifically, according to preliminary OECD data, AEOI led to a decrease of $20 \%$ to $25 \%$ in bank deposits in IFCs (OECD, 2019a).

\subsection{Global Forum's Initiative for "Exchange of Information on Request":}

Over 160 member states of the Global Forum have committed themselves to the application of the EOIR standard and the peer review process between members assesses the effective implementation of the standard. Between 2009 and 2019, more than 250,000 requests for information were received by members of the Global Forum - where annual figures are continuously on the rise. In ten years alone, EOIR has made it possible to recover almost EUR 7.5 billion of additional tax revenue globally (OECD, 2019c; Global Forum, 2020).

The EOIR standard necessitates tax authorities to provide (legal, financial, tax, etc.) information to another tax authority (i.e. on request) that is useful for the requesting tax administration to investigate and enforce its tax laws. Three types of information are at the heart of these exchanges. Namely i) accounting records; ii) bank information; and iii) ownership information of all relevant legal entities and arrangements (OECD, 2019c; Global Forum, 2020).

\subsection{Voluntary Disclosure Initiative for "Tax Transparency and Exchange of Information"}

Many developing countries have also taken the lead in positioning EOI as a tool to increase tax compliance and, therefore, revenue collection (e.g. Nigeria and South Africa in Section 3.4). Some of the initiatives undertaken on the continent and supported by the EOI include i) 'Voluntary Disclosure Programmes' on financial accounts and assets held offshore and ii) 'High Net-worth Individual' Programmes, which obviously target (potential) major taxpayers (Global Forum, 2020).

In the run-up to full implementation of the AEOI initiative, the voluntary disclosure of offshore accounts, financial assets and earnings resulted in extra revenue of more than EUR 95 billion (tax, interest and penalties) for OECD and G20 countries over the period 2009-2019 (OECD, 2019a). ${ }^{6}$

The international community has attained an unparalleled degree of accountability in tax matters, which will deliver tangible benefits for government revenues for years to come. The transparency initiatives that have been designed and implemented via the G20 have disclosed a deep pool of offshore funds that can now be properly taxed by tax authorities. Continuing assessment of cross-border financial activities is already displaying the extent to which international standards

\footnotetext{
${ }^{6}$ France, as one country example, launched a voluntary disclosure programme in 2013, prior to implementing the AEOI Standard. By September 2017, more than 50,000 taxpayers had voluntarily disclosed $€ 32$ billion in hidden assets and $€ 7.8$ billion in taxes were recovered.
} 
for automatic exchange of information have reinforced tax compliance - with potentially stronger results in the future (OECD, 2019a).

\subsection{Evidence from Country Cases}

Multilateral transparency initiatives (i.e. AEOI, EOIR and EOI) are increasingly proving to be effective in generating tax revenues not just in rich countries but also in several developing countries (middle- and lower-income). Examples of tax gains generated through the implementation of these tax transparency and information exchange standards include the following:

- Brazil reported that the total value of previously undeclared taxable foreign income disclosed during the fiscal year through a legislative or administrative disclosure mechanism or practice has reached nearly $R \$ 170$ billion in 2016 . The total tax, interest and penalties collected as a result come to almost $R \$ 47$ billion - approximately $€ 12$ billion (Monkam et al., 2018).

- Burkina Faso estimated that it would recover over 2.4 million US dollars in taxes from its first requests sent in September 2017 (Monkam et al., 2018).

- India, before its first AEOI in 2017, launched an Income Declaration Scheme in 2016 which persuaded 65,000 taxpayers to disclose assets of USD 11 billion not previously declared. The voluntary disclosure programme started on 1 June 2016 and ended on 30 September 2016. A total of USD 6 billion in tax was recovered (Monkam et al., 2018).

- Indonesia has recently recovered more than USD 10 billion in tax under an amnesty scheme developed before it introduced the CRS. Almost one million taxpayers disclosed USD 366 billion of previously undisclosed assets (Monkam et al., 2018).

- $\quad$ Nigeria launched a Voluntary Assets and Income Declaration Scheme from 1 July 2017 to 31 September 2018. This yielded about USD 82 million and grew the taxpayer database from 14 million in 2016 to 19 million in 2018 (Global Forum, 2020).

- South Africa collected USD 62.24 million through a settlement from one (major) taxpayer in 2013. The exchange of information played a determining role in the collection of tax in this case (Monkam et al., 2018).

South Africa launched a Special Voluntary Disclosure Programme which ran from 1 October 2016 to 31 August 2017. ${ }^{7}$ USD 1.8 billion worth of foreign assets were disclosed, and the revenues gained amounted to USD 296 million. These are assets that were previously hidden offshore by non-compliant taxpayers that will continue to contribute to tax revenue generation in the future (Global Forum, 2020).

South Africa has also introduced a permanent Voluntary Disclosure Programme in its tax law, offering taxpayers to come forward voluntarily to regularise their tax affairs. An amount of approximately USD 213 million was collected for the period from 1 April 2018 to 31 March 2019 under this programme. According to the South African Revenue Service (SARS), a large intake on Voluntary Disclosure Programme applications is concerning foreign assets previously not disclosed (Global Forum, 2020).

7 This programme ran prior to South Africa's first AEOI exchanges in September 2017. 
- Tunisia, for many years, had failed to benefit from the EOIR standard in the fight against tax evasion. This was because it had gaps in its legal framework and no appropriate organisation in place to deal with EOI requests. This is despite Tunisia joining the Global Forum relatively early in 2012. Fortunately, the Global Forum Secretariat has delivered intensive technical assistance to Tunisia since 2014 to help Tunisia address the obstacles to an effective EOI on both the legal framework and its operationalisation. Consequently, this assistance has resulted into major reforms in Tunisia in the areas of tax transparency, such as the creation of a beneficial ownership register and the establishment of a national database of bank accounts maintained by the tax administration. Tunisia has also benefited from trainings and other capacity-building activities from the Global Forum Secretariat in the past four years (e.g. 246 officials were trained on EOI). These efforts are already having a significant impact on Tunisia. Tunisia is now one of the most transparency engaged African countries, e.g. in terms of the number of EOI requests sent. For instance, 218 requests were sent by Tunisia in 2019 alone (Global Forum, 2020).

- Uganda, like other positive examples above, has also recovered over USD 9 million in taxes in 2015/2016 (Monkam et al., 2018). Uganda's strategic partnership with the OECD Global Forum has inspired policy and administrative reforms, which have informed the design of the National Domestic Revenue Mobilisation Strategy, specifically in areas of cross border transactions and tax transparency (Global Forum, 2020).

Mobilization of more tax revenue is anticipated as countries continue to process shared financial information, which they collect through data matching and other investigative methods. OECD states that these promising findings are just an initial survey of multilateral attempts to ensure tax transparency - both in developing and developed countries (OECD, 2019a).

Within the tax transparency and exchange of information scheme, the supply side of tax/financial information has considerably improved over the years. Currently, well over 70 tax jurisdictions have eliminated strict bank and ownership secrecy for EOI purposes. ${ }^{8}$ However, the demand side of the EOI scheme (particularly in developing countries) remains problematic. This is because few developing economies make requests and thus fail to benefit from the huge potential in the EOI tools and wide international information network (Monkam et al., 2018). For example:

- India made 10 times as many EOI requests as all African economies combined.

- The United Kingdom has made 1856 requests in 2016 alone, whereas Africa Initiative members (i.e. Cameroon, Burkina Faso, Ghana, Kenya, Liberia, Morocco, Nigeria and Uganda) have together made 79 requests in the first three years of the Africa Initiative over the 2015-17 period (Monkam et al., 2018).

\footnotetext{
8 This includes, among others, the British Virgin Islands, the Cayman Islands, Switzerland, and Panama (Monkam et al., 2018).
} 


\subsection{Evidence from Other Support Initiatives}

\section{World Bank Group and Global Forum:}

The World Bank Group (WBG) supports the global agenda for tax transparency. The WBG has committed considerable resources (in collaboration with the Global Forum) to help countries develop their capacity in EOI. Its development policy lending increasingly includes funding for work on tax transparency, which plays a key role in driving the commitment of countries and tax authorities (Global Forum, 2020).

The evidence from African countries has shown that the participation of key decision-makers (government officials, senior tax authorities, major business leaders, etc.) is of strategic significance in addressing the challenges of tax transparency in developing countries. In particular, the agenda for tax transparency in Africa has been able to step forward through a series of high-level commitments involving key decision-makers (Global Forum, 2020).

At a country level, the Global Forum and the WBG partnership provide technical assistance and capacity building to meet global tax transparency and information exchange requirements. This partnership also encourages the development of risk management systems to help classify origins of risky transactions, which may be tools for tax avoidance, tax evasion and illicit financial flows (Global Forum, 2020).

- WBG development policy lending is more and more including support for work on tax transparency. For instance, WB support to Cape Verde via technical assistance (funded by the Global Tax Program) and also a lending operation led to the country's decision to join the Global Forum. Since becoming a Global Forum member, Cape Verde has benefited from the joint Global Forum/WBG technical assistance.

- Cooperation between the WBG and the Global Forum has also led to substantial progress in the adoption of EOI standards in Latin America and the Caribbean and is currently being expanded to other regions. Countries that benefited from the Joint Global Forum/WBG Technical Assistance programmes include Cape Verde, Costa Rica, Georgia, Madagascar, Peru, Ukraine, and Viet Nam.

\section{African Union, Global Forum and African Development Bank Group:}

Major international tax transparency standards and initiatives (and EOI in particular) are extending a unique opportunity for broadening the tax base through the fight against tax evasion in developing countries. By realising this, the African Union (AU) Commission has taken part in a new partnership with the Global Forum under the framework of the Africa Initiative. The objective is to improve tax transparency in African countries so as to serve the purposes of DRM in African countries (Global Forum, 2020).

A critical mechanism for cooperation with the African Development Bank Group (AfDB) has also recently been strengthened to facilitate the adoption of tax transparency standards by African countries. The AfDB's work on tax transparency has been driven by its policy and strategic framework and action plan against IFFs, which is operational since 2017 (Global Forum, 2020). Amongst other activities, the AfDB is supporting African countries and Regional Economic Communities to: 
- Work together (and support other organisations) to support countries commitment to influence emerging global governance frameworks for international tax transparency (Global Forum, 2020). ${ }^{9}$

- Build the capacities of countries in the region to confront tax evasion, lessen opportunities for tax avoidance and accelerate recovery of stolen assets;

- Nurture cross-border co-operation among tax authorities and encourage an automatic exchange of tax information among African countries and globally;

- Assistance to the disclosure of beneficiary ownership via provision and regular update of information;

- Assisting tax administrations for effective controls and audits of both local and multinational companies; and

- Assisting tax authorities in enhancing transparency in financial transactions among governments and companies.

The Global Forum observed that the use of tax transparency and the EOI was unequal across countries. States who have joined the Global Forum early on are usually at an advanced stage in the adoption of transparency standards, whereas new participants (e.g. some African countries) are looking to put the standards in place. The difference between members and nonmember countries is much wider. The Global Forum (based on its study on Global Forum member and non-member African countries) noted that non-member countries usually share certain similar features. It has been shown that the EOI is not a priority (or a low priority) in nonmember countries; the level of knowledge on the EOI is low; the network of EOI partners is very narrow, usually between five and ten partners; the basic infrastructure (EOI unit, procedures, etc.) is almost non-existent and the EOI is not used to enforce tax legislation. For example, between 2014 and 2019, only one non-member sent two EOI requests, while 1,024 requests were sent by members in the same period. In 2019, the average number of requests sent per country was 10 for members and zero for non-members (Global Forum, 2020).

Since many major financial centres around the world have signed up to transparency standards (e.g. several rich countries, with the notable exception of the US), they are expected to share financial/tax information to countries that have adopted the transparency (and information sharing) standards and are part of the Global Forum (i.e. among 161 member countries of the Global Forum). Developing countries could, thus, have huge net recipients (e.g. recover tax revenue) from such information if they also meet these standards (Monkam et al., 2018).

\section{Tax Transparency and Citizen-State Relationship}

The ongoing efforts to promote tax compliance by promising better responsiveness and accountability must be centred on the dialogue between citizens and government about taxation. Taxpayers must be allowed, implicitly or explicitly, to convey their expectations of the government and their commitment to support those objectives through their tax contributions.

\footnotetext{
${ }^{9}$ Some examples include the Global Forum, Financial Action Task Force (FATF); FATF Style regional bodies in Africa; African Tax Administration Forum (ATAF); and the Tax Justice Network Africa (TJNA).
} 
Governments, in turn, must establish clear links between taxation, public expenditure and the achievement of the broad objectives of obtaining the support of tax-paying citizens. While governments can still collect some tax revenue without such a national dialogue, and citizens will still receive some government services, examples from Chile, Ghana and Kenya, among others, indicate that the most successful countries have fostered some degree of state-citizen tax bargaining (Prichard, 2010).

In most developing countries (particularly low-income ones) trust in tax administration and the government is very low, owing to inequitable enforcement of tax laws and a significant lack of transparency about what taxes are collected and how the money is used. Basic awareness of taxation is also limited - while taxpayers are aware that they are paying tax, too often they have only a partial understanding of how much taxes they exactly pay, why they pay taxes, and what the tax revenues are used for (Fjeldstad and Therkildsen, 2008; Prichard, 2010; Bahiigwa et al., 2004). ${ }^{10}$ The lack of information is particularly higher for indirect taxes (Prichard, 2010).

Developing countries that became most successful in tax collection (DRM) have usually made taxation more, not less, transparent. It seems that without adequate knowledge and information, taxpayers have a tendency to assume the worst and place little trust in their tax authorities. Even if governments are often hesitant to share information about tax incidence (often because they are concerned about public opposition), they should realize that the absence of accurate information can also lead to problems (Prichard, 2010).

- Ghana: When the country first introduced VAT in 1995, a lack of effective public education led to rumours among the public about large price increases, even though such price rises were often false and were driven by a misunderstanding of the new tax (Prichard, 2009).

- Uganda: When the country adopted a VAT in 1996, public misunderstanding appears to have played a big part in triggering major protests, as rumours circulated that there would be considerable price increases. There were also some unintentionally misleading statements made by officials about the tax, and this seems to have added to the confusion (Therkildsen, 2011; Prichard, 2010).

The ongoing efforts by developing country governments (and their development partners) to enhance transparency must incorporate better reporting of revenue collection and compliance, nurturing a national dialogue about tax-expenditure connections, issuing information about public spending by type/project and by administrative location, "naming and shaming" tax evaders, and perhaps making use of revenue earmarking to create clear connections between taxes and expenditures (Prichard, 2010).

The generally low taxpayers' compliance that is witnessed in developing countries is moulded to a large degree by i) whether or not citizens/taxpayers believe that other taxpayers are paying their fair share; ii) how much taxpayers believe that the tax revenue is being used effectively (i.e. without corruption or waste on vanity projects) and iii) whether or not taxpayers believe that national tax administration is honest and fair (Fjeldstad, 2004). All of these forms of trust are weakened in many developing countries by a

\footnotetext{
10 See also Gloppen and Rakner (2002) and Fjeldstad and Semboja (2001).
} 
deficiency of transparency around tax collection, tax compliance and the use of tax revenue at both the national and local levels. There is reason to think that enhancing transparency could improve tax compliance while enabling citizen engagement in political discussions of taxation and public spending (Prichard, 2010).

Considering the low levels of trust among taxpayers in many developing countries, the key task for governments will be rebuilding public confidence in the tax system (and public administration in general). Based on their study of rural taxation in Uganda, Bahiigwa et al. (2004) suggest that rebuilding trust from a low level should rely on improving explicit linkages between tax collection and public expenditure. Their proposals include: (i) working in direct contact with neighbourhood groups to collect personal tax; (ii) publicly and regularly communicating how the amounts of tax collected measure up to expectations; and (iii) clarifying the specific implications of changes in collection for public spending. Prichard (2010) also notes the importance of making budget and expenditure data accessible to tax-paying citizens so as to build public support for taxation.

\section{Some examples of the potential benefits of tax transparency - especially emanating from linking taxation and expenditure in developing countries include:}

- Constituency Development Funds (CDF) in Kenya: The creation of CDF has been contentious in many respects but it offers a persuasive example of the potential for transparency and improved tax-expenditure linkages to substantially affect levels of citizen engagement.

CDFs in Kenya assigned a fixed share of central government revenue to each district and grant primary control over allocations to the local MP. While Kenyan CDFs have partly garnered a positive reception, they have also been condemned both for bypassing and weakening local authorities, and for possibly creating room for corruption, at least in part, due to their politicisation and ineffective accountability mechanisms. Yet, amidst these key debates, there appears to be a general sense that the CDFs have succeeded in improving the understanding of citizens regarding the links between taxation and public service delivery. In some cases, the CDFs have also encouraged public engagement.

Some of the changes in the attitudes of citizens regarding taxation appear to have resulted from the efforts by the central government to underscore these tax-expenditure linkages by being transparent about resource transfers and highlighting the message that "this is your money". However, the Kenyan experience does not necessarily justify the universal use of CDFs in wider contexts. It, nonetheless, underlines the potential for transparency and education to enhance the basis for citizen engagement with tax and expenditure issues in developing countries (Prichard, 2010).

- USAID project on market taxes in Guinea: Market taxes are an important revenue source for local governments in Guinea, as is the case in many developing countries in the region. However, they are also poorly collected and unpopular among citizens. The project made an agreement with the government to directly and explicitly link the collection of market taxes to the construction of improved market facilities. The scheme, then, displayed clear information about revenues and expenditures in nearby public places (i.e. both for market taxes as well as other taxes in general).

These fairly forthright measures has resulted in the doubling of tax revenues collected from the markets in one year. This was due to better tax compliance by tax-paying citizens and improved community monitoring of the behaviour of tax collectors. The 
government of Guinea noted that this increase in tax revenue was sustained - following the replication of the project in wider parts of the country. However, the levels of success differed from place to place (Korsun and Meagher, 2018; Prichard, 2010).

A rather direct way to enhance tax transparency, strengthen linkages between taxation and expenditure and rebuild public trust in the tax system is to work directly with community organisations in collecting tax revenue (Prichard, 2010).

- In Ghana, for instance, the government instituted a system of 'associational taxation' in order to tax the informal sector. Tax collection powers were given to small business associations under this system - with the belief that they would then pass on the revenue to the government at the end of a pre-defined period of time. The system did succeed in steering considerable parts of the informal sector into the tax net - with a minor degree of resistance, while at the same time delivering discrete benefits to 'new' taxpayers, such as reduced harassment by police and better political legitimacy (Joshi and Ayee, 2008; Prichard, 2009).

\section{Tax Transparency and Rule of Law}

Accountability to the rule of law (i.e. in relation to paying taxes) can be improved by providing clear and transparent incentives for citizens and government to enter into a "tax bargain" or "fiscal contract". In this process, tax-paying citizens accept and comply with taxes in return for the government providing them with effective public services, ensuring the rule of law and accountability. Such 'tax bargains, between citizens and the state are mutually beneficial, because citizens enjoy better governance while the government obtains bigger and more predictable tax revenues - which also minimises administrative costs as taxes become easy to collect. Most developing country governments have historically failed to implement highly effective tax systems - and the few that succeeded have first held a national dialogue about taxation with their citizens and entered into a tax contract (Prichard, 2010).

Tax transparency (and broadly transparency in public administration) has been associated with good governance (Hood 2007; Hansen et al. 2014; Hansen et al. 2015) and with greater democracy (Neyland, 2007). In line with this, there is a great demand for more information (e.g. from general pleas to specific freedom of information requests) in the quest to achieve greater transparency in developing countries (Oats and Tuck, 2019).

Conversely, the tax systems remain basically 'coercive' in many developing countries. These tax systems provide benefits and exemptions for elites and, because of this, citizens have little faith in them. Studies (Oats and Tuck, 2019; Prichard, 2010) indicate that a consensual tax bargain is more likely when taxpayer knowledge and education are high; the tax system is transparent and reveals tax-expenditure linkages; citizens have shared interests and a high level of mutual trust on the tax system; taxpayers are organised politically; and voluntary tax compliance is emphasised by tax authorities.

A good understanding of tax transparency by citizens is a necessary condition for building public commitment and trust. Without a reasonable degree of trust in the tax system, taxation is likely to be characterised by conflict rather than cooperation. Citizens need to be aware of the taxes they pay and to be educated about the tax and budgeting system, 
while governments need to be transparent about tax collection and public spending (Prichard, 2010).

- At the local level, transparency can be achieved by publicising the collection of revenue and linking it to public spending in the administrative locality, and by engaging citizens directly i) during the budgeting for public expenditures; ii) while raising tax revenue; and iii) while auditing or in the assessment processes of revenues and expenditures.

- At the national level, governments can do far more to share revenue information, to make transparent estimates of tax compliance and revenue performance, and to monitor tax incentives for citizens (and also their costs) more closely.

Tax systems that are less transparent (e.g. in the areas of personal income taxes and natural resources) and less fair (e.g. big compliance gaps by national elites and the informal sector) weaken the legitimacy of tax systems in the eyes of taxpayers. Uneven tax compliance undercuts the trust citizens have in the tax system and entrenches the belief that others are not paying their share. When taxpayers do not share a common set of interests and when the government cannot be trusted by its citizens, the tax bargaining process becomes difficult and coercive. Therefore, it is important to make taxation appear fair - e.g. through taxing the informal sector as well as fairly and regularly taxing powerful elites and their businesses (although this may be politically more challenging in many developing countries).

Enhancing direct (i.e. personal) taxation would increase tax equity and increase the visibility (i.e. transparency) of taxes. This is likely to increase awareness, increase trust among taxpayers, and increase trust between taxpayers and the government, all of which are likely to make public engagement and tax negotiations more likely. Nevertheless, direct taxes make up a dramatically lower share of income in developing countries than in rich countries. Further, property taxes are an especially politically and administratively difficult issue, but they deserve renewed consideration as part of both a governance-enhancing and DRM reinforcement plan (Prichard, 2010).

\section{Potential Costs of Tax Transparency}

Adhering to rigorous tax transparency standards by companies entails providing information that allows society (i.e. both citizens and state authorities) to evaluate their activities. Tax transparency standards are often adopted as a means to some other end (e.g. make sure that they pay their fair share of taxes), rather than as a goal in itself (Nielson and Madsen, 2009; Oats and Tuck 2019). As such, if tax transparency mainly entails i) more work for businesses in providing large volumes of tax/financial data and ii) more work for tax authorities in analysing this voluminous data, iii) yet fail to translate to meaningful gain (e.g. in generate more tax revenue), then one can argue of it to be 'costly'.

Therefore, tax transparency can be a costly regulatory strategy, not only for the providers of the information but also for those that are expected to process the information.

Burdening tax authorities with extra information processing requirements may not be effective at a time when they are working under serious resource constraints. The cost of complying with and monitoring tax transparency measures will ultimately be borne by society by straining the resources of the tax authorities and by companies seeking to recover costs, for example through 
higher prices for the goods and services they supply (Oats and Tuck, 2019). As Freedman (2018) points out, excessive information may obscure and even become a convenient excuse to conceal business activities.

In both public and scholarly debates on tax regulation, the prevailing wisdom appears to be that more tax transparency is better. It has been argued that transparency increases accountability and strengthen the hand of tax authorities. Nevertheless, overloading regulators with information may also create capacity problems as well as may lead to confusions and mistakes. The introduction of strong transparency standards may help to force the disclosure of (otherwise hidden) information by businesses, individual taxpayers and even the government. However, with increased transparency and visibility, the ability of regulators to differentiate between relevant and irrelevant information might become impaired. In such cases, transparency may not achieve the positive objectives sought by its advocates (Oats and Tuck, 2019).

Forcing the financial centres in rich countries (i.e. those with an extensive degree of legal, institutional, and technological sophistication) to share information automatically and to start doing so in a brief period is feasible and useful. However, when countries with considerable socio-political and institutional constraints (e.g. many low-income developing countries) quickly adopt strong multilateral transparency standards, they may face capacity challenges. In fact, such circumstances may place them in the dilemma of either i) be noncompliant with the transparency standards or ii) be forced to pass reforms at speed, which is not always achievable or even suitable (Barreix et al., 2016).

\section{Factors Limiting Wider Adoption of Tax Transparency Initiatives}

Some of the difficulties limiting the wider adoption of tax transparency standards (especially among developing countries) stem from the fact that these instruments were not developed in proper consultation with developing countries. As a consequence, the standards sometimes fail to reflect the concerns, priorities, and capacities of developing economies. For instance, even though a number of countries have now signed up to the AEOI standard implemented by the Global Forum, most African countries did not have the opportunity to influence its design. Instead, they were faced with a done deal - i.e. with the option to either take or leave a transparency standard that had already been developed. It is, therefore, understandable that many developing countries are making only limited use of such tools. In order to boost the use of these transparency processes, developed countries may need to introduce flexibilities for developing countries - in line with their limited capacities. They could either i) modify the implementation process of the existing standards ii) complement the standards with additional measures that better serve the needs of developing countries or iii) or modify the transparency standards themselves (Monkam et al., 2018).

Some of the general factors limiting the automatic exchange of tax information can be summarized as follows (Monkam et al., 2018):

- Developing countries face difficulties in raising/allocating the investment required to realise the automatic exchange of tax information. 
- There are privacy issues and data safeguarding mechanisms that are extensively in place in many developing countries. Revenue administrations in poor countries also find it challenging to adequately demonstrate physical security in all parts of their organisation (e.g. biometrics or access control for all their staff). Furthermore, they must employ security software, encryption tools, and policies and procedures that must conform to ISO standards. These technical requirements can be costly - particularly for revenue administration that are still using poor information technology architecture, requiring extensive updates.

- Financial institutions are compelled to automatically reveal financial account information of non-residents to tax administrations, which will in turn exchange this information with the tax administrations of the account holders' country of residence. This is because the financial information exchange process takes place on a reciprocal basis. However, this process is burdensome in the context of the limited tax administrative capacity in developing countries.

- Multiparty transparency standards entail cooperation between stakeholders - including businesses and the financial industry. To facilitate good working relationships in such a cooperation, revenue administrations require skilled personnel - which developing countries have a shortage of.

- To effectively use and benefit from the information received under tax transparency and information exchange standards, revenue administrations in developing countries must invest in risk identification systems and auditing skills.

- Apart from the numerous costs and capacity limitations, the benefits to developing countries of implementing the tax transparency standard may not always be clear although there have been successes. Furthermore, several concerns have been mentioned regarding gaps in the transparency standard that may enable businesses and individual taxpayers to avoid their accounts from being caught up in the information that is being reported (TJN, 2015). Besides, the information obtained multilateral transparency standards, e.g. through AEOI, can only be used for tax administration purposes (i.e. will not be shared with other law enforcement agencies), thus, reducing its usefulness for developing countries. 


\section{References}

AU and ECA (2015). Report of the High-Level Panel on Illicit Financial Flows from Africa commissioned by the AU/ECA Conference of Ministers of Finance, Planning and Economic Development. African Union and United Nations Economic Commission for Africa. https://repository.uneca.org/bitstream/handle/10855/22695/b11524868. pdf?sequence=3\&isAllow ed $=y$

Bahiigwa, G., F. Ellis, O.-H. Fjeldstad and V. Iversen, (2004). Rural Taxation in Uganda: Implications for Growth, Income Distribution, Local Government Revenue and Poverty Reduction. EPRC Research Series, No. 35, Economic Policy Research Center, Kampala. https://www.cmi.no/publications/file/1735-rural-taxation-in-uganda-implications-for-growth.pdf

Barreix, A. D., Roca, J., \& Velayos, F. (2016). A brief history of tax transparency (Vol. 11). u: Discussion Paper NIDB-DP-453, IDB.

https://publications.iadb.org/publications/english/document/A-Brief-History-of-Tax-

Transparency.pdf

ECA (2018). A study on the global governance architecture for combating illicit financial flows. United Nations Economic Commission for Africa.

https://repository.uneca.org/bitstream/handle/10855/24320/b1188924x.pdf?sequence=3\&isAllow ed $=y$

Fjeldstad, O.-H. (2004). What's Trust Got To Do With It? Non-Payment of Service Charges in Local Authorities in South Africa. Journal of Modern African Studies, Vol. 42, No. 4, pp. 539-562. https://doi.org/10.1017/S0022278X04000394

Fjeldstad, O.-H. and J. Semboja (2001). Why People Pay Taxes: The Case of the Development Levy in Tanzania. World Development, Vol. 29, No. 12, pp. 2059-2074. https://doi.org/10.1016/S0305-750X(01)00081-X

Fjeldstad, O.-H. and O. Therkildsen (2008). "Mass Taxation and State-Society Relations in East Africa", in D. Brautigam, O.-H. Fjeldstad and M. Moore (ed.), Taxation and State Building in Developing Countries: Capacity and Consent, Cambridge University Press, Cambridge. https://doi.org/10.1017/CBO9780511490897

Freedman, J., (2018). Restoring trust in the 'fairness' of corporate taxation: increased transparency and the need for institutional reform. In: S. Goslinga, et al., eds. Trust and Taxation. The Hague: Eleven, 121-141. https://dx.doi.org/10.2139/ssrn.3396775

Global Forum (2020). Tax Transparency in Africa 2020 Africa Initiative Progress Report: 2019. Global Forum on Transparency and Exchange of Information for Tax Purposes. https://www.oecd.org/tax/transparency/documents/Tax-Transparency-in-Africa-2020.pdf

Gloppen, S. and L. Rakner (2002). Accountability Through Tax Reform: Reflections from SubSaharan Africa. IDS Bulletin, Vol. 33, No. 3.

http://www.ids.ac.uk/files/dmfile/IDSOpenDocsStandardTermsOfUse.pdf

Hansen, H., Christensen, L. and Flyverbom, M., (2015). Introduction: logics of transparency in late modernity: paradoxes, mediation and governance. European Journal of Social Theory, 18 (2), 117-131. https://doi.org/10.1177\%2F1368431014555254 
Hansen, H.K. and Flyverbom, M., (2014). The politics of transparency and the calibration of knowledge in the digital age. Organization, 22 (6), 872-889.

https://doi.org/10.1177\%2F1350508414522315

Hood, C., (2007). What happens when transparency meets blame-avoidance? Public Management Review, 9 (2), 191-210. https://doi.org/10.1080/14719030701340275

IMF, OECD, UN and World Bank (2011). Supporting the Development of More Effective Tax Systems, A Report to the G20 Development Working Group, OECD, Paris, www.oecd.org/ctp/48993634.pdf

Joshi, A. and J. Ayee (2008). "Associational Taxation: A Pathway into the Informal Sector", in D. Brautigam, O.-H. Fjeldstad and M. Moore (ed.), Taxation and State Building in Developing Countries: Capacity and Consent, Cambridge University Press, Cambridge. https://doi.org/10.1017/CBO9780511490897

Korsun, G. and P. Meagher (2018). "Failure by Design? Fiscal Decentralization in West Africa", in M. Kimenyi and P. Meagher (ed.), Devolution and Development: Governance Prospects in Decentralizing States, Ashgate, London. https://doi.org/10.4324/9781351160001

Monkam, N., Ibrahim, G., Davis, W., \& von Haldenwang, C. (2018). Tax transparency and exchange of information (EOI): Priorities for Africa (T20 Argentina Policy Brief). https://www.g20insights.org/wp-content/uploads/2018/07/TF5-5.2-Taxation_FINAL-1.pdf

Neyland, D., 2007. Achieving transparency: the visible, invisible and divisible in academic accountability networks. Organization, 14 (4), 499-516.

https://doi.org/10.1177\%2F1350508407078050

Nielson, C. and Madsen, M.T., (2009). Discourses of transparency in the intellectual capital reporting debate: moving from generic reporting models to management defined information. Critical Perspectives on Accounting, 20, 847-854. https://doi.org/10.1016/j.cpa.2008.09.007

Oats, L. and Tuck, P. (2019). Corporate tax avoidance: is tax transparency the solution? Accounting and Business Research, 49:5, 565-583.

https://doi.org/10.1080/00014788.2019.1611726

Oats, L., \& Tuck, P. (2019). Corporate tax avoidance: is tax transparency the solution?. Accounting and Business Research, 49(5), 565-583.

https://doi.org/10.1080/00014788.2019.1611726

OECD (2018). Countries must strengthen tax systems to meet Sustainable Development Goals. OECD. www.oecd.org/tax/countries-must-strengthen-tax-systems-to-meetsustainabledevelopment-goals.htm

OECD (2019a). Implementation of tax transparency initiative delivering concrete and impressive results. OECD. https://www.oecd.org/tax/implementation-of-tax-transparency-initiative-deliveringconcrete-and-impressive-results.htm

OECD (2019b). Tax Morale: What Drives People and Businesses to Pay Tax?, OECD

Publishing, Paris, https://doi.org/10.1787/f3d8ea10-en 
OECD (2019c). Transparency and Exchange of Information for Tax Purposes Multilateral Cooperation Changing the World, 10th anniversary report, www.oecd.org/tax/transparency/globalforum-10-years-report.pdf

OECD, ATAF and AUC (2019). Revenue Statistics in Africa 2019, http://oe.cd/revenue-statisticsin-africa

Prichard, W. (2009). The Politics of Taxation and Implications for Accountability in Ghana 19812008. IDS Working Paper, No. 330, Institute of Development Studies, Brighton.

https://doi.org/10.1111/j.2040-0209.2009.00330_2.x

Prichard, W. (2010). Citizen-State Relations: Improving governance through tax reform. Paris: Organisation for Economic Cooperation and Development, 30, 32-36.

https://www.oecd.org/dac/conflict-fragility-resilience/governance/docs/46008596.pdf

Schnackenberg, A. K., \& Tomlinson, E. C. (2016). Organizational transparency: A new perspective on managing trust in organization-stakeholder relationships. Journal of Management, 42(7), 1784-1810. https://doi.org/10.5465/ambpp.2016.14480abstract

Therkildsen, O. (2011). Autonomous Tax Administration in Sub-Saharan Africa: The Case of the Uganda Revenue Authority", Forum for Development Studies, Vol. 3, No. 1, pp. 59-88. https://doi.org/10.1080/08039410.2004.9666264

TJN (2015). OECD's Handbook for Implementation of the CRS: TJN's preliminary observations. September 15, 2015. Tax Justice Network. https://dx.doi.org/10.2139/ssrn.2943981

\section{Suggested citation}

Megersa, K. (2021). Tax Transparency for an Effective Tax System. K4D Helpdesk Report 942. Brighton, UK: Institute of Development Studies. DOI: 10.19088/K4D.2021.070

\section{About this report}

This report is based on six days of desk-based research. The K4D research helpdesk provides rapid syntheses of a selection of recent relevant literature and international expert thinking in response to specific questions relating to international development. For any enquiries, contact helpdesk@k4d.info.

K4D services are provided by a consortium of leading organisations working in international development, led by the Institute of Development Studies (IDS), with Education Development Trust, Itad, University of Leeds Nuffield Centre for International Health and Development, Liverpool School of Tropical Medicine (LSTM), University of Birmingham International Development Department (IDD) and the University of Manchester Humanitarian and Conflict Response Institute (HCRI).

This report was prepared for the UK Government's Foreign, Commonwealth and Development Office (FCDO) and its partners in support of pro-poor programmes. It is licensed for non-commercial purposes only. Except where otherwise stated, it is licensed for non-commercial purposes under the terms of the Open Government Licence v3.0. K4D cannot be held responsible for errors, omissions or any consequences arising from the use of information contained in this report. Any views and opinions expressed do not necessarily reflect those of $F C D O, K 4 D$ or any other contributing organisation.

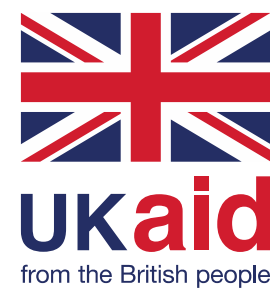

(C) Crown copyright 2021. 